\title{
Understanding access to the labour market through migration channels
}

\section{Laure Sandoz}

Institute of Cultural Anthropology and European Ethnology, University of Basel laure.sandoz@unine.ch; http://orcid.org/0000-0002-9058-6572

The mobility of the 'highly skilled' has become widely researched but only a few researchers have approached this category of migrants from a critical perspective. This article argues that understanding how 'highly skilled migrants' are constructed necessitates considering the conditions in which migration takes place as well as the perceptions and practices associated with these conditions. It uses the concept of 'migration channels' to investigate the enabling and disabling factors associated with different migration situations. The analysis draws on biographic interviews with highly educated migrants in Switzerland, and supplements these with expert interviews and ethnographic observations of people working in institutions that support, guide, or control migrants' access to the labour market. The article shows that categories of migrants are artificial and often do not coincide with lived realities. Migrants actively develop strategies to achieve their personal aspirations, but they also depend on the opportunities available in their environment. The concept of 'migration channels' enables us to capture this interplay between structures and agency by showing how different actors shape the opportunities and constraints faced by different groups of migrants, and how migrants actively deal with them. This concept thus fosters a critical yet empathic understanding of migration experiences.

Keywords: highly skilled migrants; migration channels; labour-market access; migration intermediaries 
This is a preprint version of an article published in the Journal of Ethnic and Migration Studies:

Laure Sandoz (2018) Understanding access to the labour market through migration channels, Journal of Ethnic and Migration Studies, DOI: 10.1080/1369183X.2018.1502657

\section{Introduction}

Over the past two decades, the mobility of the highly skilled has become widely researched (Boucher and Cerna 2014, Yeoh and Huang 2011). In politics, attracting highly skilled workers has become a priority for many industrialised countries (OECD 2008), and most scholars have focused on analysing the appeal of skill-focused policies and on assessing the efficiency of human-capital transfers across borders (Cerna 2013, Docquier, Lohest, and Marfouk 2005). Only a few researchers, however, have approached the category of highly skilled migrants from a critical perspective (Favell, Feldblum, and Smith 2006).

This article uses a case-study of highly educated migrants in Switzerland to investigate the opportunities and obstacles associated with different migration channels. It highlights the roles and responsibilities of the state and other actors for developing support structures available to migrants using each channel. The analysis contributes to the larger body of literature on the construction of migrant categories by highlighting the fact that skills are not always the most relevant elements of classification for understanding the position of migrants in society. Categories are artificial and often do not coincide with lived realities. Moreover, migrants are active agents who may manipulate categories to expand their options. Analysing the conditions under which migration takes place and the perceptions associated with these conditions is important for understanding migrants' access to opportunities in the arrival country.

\section{Theoretical approach}

Many studies focus on the reasons why substantial numbers of highly skilled migrants lose their qualifications and become unemployed. The obstacles most often mentioned are the discrepancy between migrants' skills and local needs (Boswell, Stiller, and 
This is a preprint version of an article published in the Journal of Ethnic and Migration Studies:

Laure Sandoz (2018) Understanding access to the labour market through migration channels, Journal of Ethnic and Migration Studies, DOI: 10.1080/1369183X.2018.1502657

Straubhaar 2004), the lack of recognition for their foreign qualifications (Sommer 2016), the difficulty for newcomers to access information and support (Riaño 2003, Raghuram 2004, Riaño 2011), discrimination against certain groups (Zschirnt and Ruedin 2016), and the legal situation of migrants, which positions them unfavourably with regard to accessing jobs and negotiating labour conditions (Lowell and Avato 2014, Berthoud 2012).

There has been, however, less research on how migrants access highly skilled jobs. Yet, several authors have observed the multiplication of agents involved in monitoring the mobility of highly skilled migrants (Bruland and Rusten 2011, Van Riemsdijk, Basford, and Burnham 2015, Xiang 2007). They have argued that this proliferation of agents creates new inequalities regarding access to information and support as well as new dependencies between migrants and intermediaries (Cranston, Schapendonk, and Spaan 2017, Van den Broek, Harvey, and Groutsis 2015). Even though highly skilled migrants are often viewed as more autonomous and economically independent than less-privileged migrants (Favell, Feldblum, and Smith 2006), research shows that intermediaries play a crucial role in matching migrants with jobs and providing them with resources for organising their daily lives.

Research on both dequalification and migration intermediaries highlights the fact that the possibilities for individuals to access new labour markets and use their skills after migration do not only depend on the nature of their skills. The institutional environments in which migrants are embedded are important because they influence the kind of information and support that they can access and the range of choices they can make. It thus appears necessary to take a closer look at these environments in order to understand how highly educated migrants access jobs and opportunities. 
This is a preprint version of an article published in the Journal of Ethnic and Migration Studies:

Laure Sandoz (2018) Understanding access to the labour market through migration channels, Journal of Ethnic and Migration Studies, DOI: 10.1080/1369183X.2018.1502657

While several authors have emphasised the importance of the interplay between individual stories and institutional structures in migration research (Xiang and Lindquist 2014, Goss and Lindquist 1995), few of them have gone so far as to compare different migration situations and institutional embeddedness. For instance, refugees are rarely the focus of studies on highly skilled migration, nor are highly skilled migrants the focus of studies on asylum (Mozetic 2018). Yet I argue that comparing different cases enables us to better understand how migration situations structure opportunities and obstacles for migrants. Such comparisons highlight the constructed nature of the categories we use for describing migrants, because they show that these categories rely not only on migrants' characteristics but also on their institutional environment.

'Migration channel' is an interesting concept for analysing the interplay between institutional contexts and migrants' experiences. It was first developed by Findlay (1990) and later explored by Findlay and different co-authors for specific case-studies (Findlay and Li 1998, Findlay and Garrick 1990, Findlay et al. 2013). Research using this concept has focused on the role of private-sector intermediaries in 'channelling' flows of migrants into different labour markets. More recently, the term 'migration channels' has been used in the context of the so-called 'migration crisis' in Europe. Various organisations, researchers, and activists have criticised the lack of opportunities for people in need of protection to travel legally to Europe and have advocated for the creation of safer migration channels (OHCHR 2016, European Commission 2016, Collett, Clewett, and Fratzke 2016). In this context, 'channel' has come to refer to the legal pathways that regulate access to national territories.

In this article, I define migration channels as mobility pathways structured by different actors (states, profit-oriented actors, third-sector actors, and individual social 
This is a preprint version of an article published in the Journal of Ethnic and Migration Studies:

Laure Sandoz (2018) Understanding access to the labour market through migration channels, Journal of Ethnic and Migration Studies, DOI: $\underline{10.1080 / 1369183 X .2018 .1502657}$

ties) that create specific opportunities and constraints for migrants. I argue that this concept is useful for observing the interrelated effect of private-sector and state-related actors on migrants' trajectories. It highlights the complex relations between different analytical levels (economic, legal, and social) and their effect on individual stories.

\section{Research context}

Processes of globalisation have not created a borderless world (Yuval-Davis, Wemyss, and Cassidy 2017). Although access to international mobility has increased on average during the past 50 years, national borders have become more selective (Mau et al. 2012). Citizens of rich countries have gained new mobility rights, but such rights have stagnated or even diminished for other regions (Mau et al. 2015).

In a context of growing international competition, governments have developed strategies to promote their economic dynamism while maintaining sovereignty over their borders. The development of skill-focused immigration programmes in postindustrialising countries has given rise to new selective border regimes aimed to attract 'the best and the brightest' while preventing the immigration of 'unwanted' people (Parsons et al. 2014). In this context, nationality and skills have become central criteria for selecting migrants and defining their residence rights (Hercog and Sandoz 2018b).

This process is observable in most European countries, including Switzerland. Although Switzerland is not part of the European Union (EU), it belongs to the European Free Trade Association (EFTA) and therefore applies a dual admission system similar to that of other EU countries: it grants free movement to the citizens of EU/EFTA member states while limiting the admission of "qualified workers from third countries' to those who are 'absolutely needed' (Swiss Federal Council 2002, 3473, quoted in Sandoz 2016b). Non-EU/EFTA citizens can only enter Switzerland as asylum 
This is a preprint version of an article published in the Journal of Ethnic and Migration Studies:

Laure Sandoz (2018) Understanding access to the labour market through migration channels, Journal of Ethnic and Migration Studies, DOI: 10.1080/1369183X.2018.1502657

seekers, reunified family members, students, or highly skilled workers, and labour migrants from non-EU/EFTA countries need the support of an employer to legally stay and work in the country.

Statistics suggest that the current situation of the Swiss labour market is particularly favourable to highly qualified migrants (OECD/EU 2015). Today, more than $60 \%$ of the adults migrating to Switzerland have completed a tertiary education (nccr - on the move 2017). ${ }^{1}$ Moreover, in 2013, Switzerland was one of the only Organisation for Economic Co-operation and Development (OECD) member countries where foreign-born highly educated individuals were less likely to be overqualified for their jobs than highly educated individuals born in the country, besides Turkey, Poland and the Slovak Republic.

Several reasons contribute to this situation, including the fact that salaries are generally higher in Switzerland than in other EU countries, the generous tax policy, the country's position in the middle of Europe, the stable political environment, the low unemployment rate, and the international outreach of the economy (Müller-Jentsch 2008). The dual admission system that prioritises immigration from the EU and of highly qualified workers from third countries also contributes to the filtering of newcomers. Today, two thirds of the people settling in Switzerland come from EU/EFTA countries, in particular from the main neighbouring countries Germany, Italy, and France (nccr - on the move 2017). A majority of them have an employment contract or job offer on their arrival, and about a third receive support from an employer

\footnotetext{
${ }^{1}$ In Switzerland, tertiary education includes universities, Hochschulen (universities of applied sciences), and postgraduate professional training.
} 
This is a preprint version of an article published in the Journal of Ethnic and Migration Studies:

Laure Sandoz (2018) Understanding access to the labour market through migration channels, Journal of Ethnic and Migration Studies, DOI: 10.1080/1369183X.2018.1502657

to help organise their move (Sandoz and Santi [forthcoming in 2018]). In contrast, the employers less actively recruit people from non-EU/EFTA countries for which it is more difficult to obtain work permits. Only $12 \%$ of West Africans and $20 \%$ of Latin Americans have an employment contract on their arrival in Switzerland (nccr - on the move 2017). This implies that most migrants from these regions legitimise their right to stay in Switzerland using family or educational reasons.

The above overview of the migration situation in Switzerland highlights an important fact: opportunities to migrate are unequally distributed because of selective migration regimes that favour certain characteristics over others (Kaufmann, Bergman, and Joye 2004). Migrant categories are not neutral, because they rely on political, economic, and social dynamics that normatively construct migrants according to culturally situated values (Tannock 2011, Kofman 2014, Boucher and Cerna 2014).

In this article, I will demonstrate that migration channels constitute different opportunities and constraints for migrants not only during migration but also after it. As other authors have shown, borders are not only a physical line of delimitation between territories; they also affect every-day practices of inclusion and exclusion within states (Yuval-Davis, Wemyss, and Cassidy 2017). Migration channels are a reflection of these bordering processes because they associate specific values and rights with specific groups of migrants.

\section{Methods}

The analysis is based on ethnographic research conducted in 2014 and 2015. The data corpus consists of 13 semi-directed biographic interviews with highly qualified migrants who moved to Switzerland as adults and searched for a job in the country; 16 expert interviews with people working in institutions that support, guide, or control 
This is a preprint version of an article published in the Journal of Ethnic and Migration Studies:

Laure Sandoz (2018) Understanding access to the labour market through migration channels, Journal of Ethnic and Migration Studies, DOI: 10.1080/1369183X.2018.1502657

migrants' access to the labour market (e.g. state representatives, human resources specialists, professional recruiters, job coaches and relocation agents); and numerous observations at events that aim at informing and supporting skilled migrants during their job search.

The biographic interviews focused on people who had trouble finding a job after their arrival in Switzerland, that is, people who encountered difficulties in getting recognised as highly skilled professionals in their new environment. Analysing situations of potential rupture, conflict, or self-reassessment for the people involved enabled me to better understand the limits of commonly used categories and of the social mechanisms behind their construction.

I followed a theoretical sampling approach, which involved constant iterations between data collection, data analysis, and reading relevant literature (Glaser and Strauss 1967). Connecting the stories of the interviewees with my ethnographic observations and the information provided by migration experts, employers, and labour market intermediaries helped me to situate each interview within its broader institutional context.

I accessed the interviewees through various means. I mainly used the Internet to identify relevant actors and collect preliminary information. I also used the snowball sampling technique (Atkinson and Flint 2004), which was useful not only for accessing more people but also for understanding my interviewees' relational networks better. Participation in public events (e.g. information events about integration, labour market access, migration management and corporate mobility) enabled me to reach potential interviewees, exchange preliminary information, and decide whether to meet them 
This is a preprint version of an article published in the Journal of Ethnic and Migration Studies:

Laure Sandoz (2018) Understanding access to the labour market through migration channels, Journal of Ethnic and Migration Studies, DOI: 10.1080/1369183X.2018.1502657

again. Finally, I partly relied on my personal network in Switzerland to contact interviewees.

The coding approach was mainly inductive and focused on correlating the support structures identified through the ethnographic field research with the migration histories of my interviewees. This process led me to define and characterise the four different channels presented in the next chapter.

Table 1. Summary of the main characteristics of the interviewees (biographic interviews)

\begin{tabular}{|c|c|c|c|c|c|c|}
\hline $\begin{array}{l}\text { Year } \\
\text { of } \\
\text { arrival }\end{array}$ & Age & Sex & $\begin{array}{l}\text { Country } \\
\text { of origin }\end{array}$ & Field of study & $\begin{array}{l}\text { Occupation upon } \\
\text { interview }\end{array}$ & $\begin{array}{l}\text { Migration channels } \\
\text { involved }\end{array}$ \\
\hline 2011 & $\sim 30$ & $M$ & Brazil & Engineering & $\begin{array}{l}\text { R\&D project } \\
\text { manager }\end{array}$ & Study-oriented channel \\
\hline 2006 & $\sim 40$ & $M$ & Germany & $\begin{array}{l}\text { History; } \\
\text { Anthropology }\end{array}$ & $\begin{array}{l}\text { Professional } \\
\text { recruiter }\end{array}$ & Study-oriented channel \\
\hline 2010 & $\sim 30$ & $M$ & Italy & $\begin{array}{l}\text { European } \\
\text { Studies }\end{array}$ & Unemployed & Study-oriented channel \\
\hline 2014 & $\sim 40$ & $M$ & Colombia & Finance & $\begin{array}{l}\text { Senior financial } \\
\text { analyst }\end{array}$ & $\begin{array}{l}\text { Company-oriented } \\
\text { channel }\end{array}$ \\
\hline 2013 & $\sim 40$ & $\mathrm{~F}$ & Greece & Medicine & $\begin{array}{l}\text { Medical affairs } \\
\text { manager }\end{array}$ & $\begin{array}{l}\text { Company-oriented } \\
\text { channel }\end{array}$ \\
\hline 2014 & $\sim 50$ & $M$ & $\begin{array}{l}\text { United } \\
\text { Kingdom }\end{array}$ & $\begin{array}{l}\text { Environmental } \\
\text { sciences; } \\
\text { Business }\end{array}$ & $\begin{array}{l}\text { Contractor through } \\
\text { a temporary } \\
\text { staffing agency }\end{array}$ & $\begin{array}{l}\text { Company-oriented } \\
\text { channel }\end{array}$ \\
\hline 1990 & $\sim 50$ & $\mathrm{~F}$ & $\begin{array}{l}\text { United } \\
\text { States }\end{array}$ & Architecture & $\begin{array}{l}\text { Head of a } \\
\text { relocation agency }\end{array}$ & $\begin{array}{l}\text { Company-oriented } \\
\text { channel }\end{array}$ \\
\hline 2006 & $\sim 30$ & $\mathrm{~F}$ & Brazil & $\begin{array}{l}\text { Linguistics; } \\
\text { Media }\end{array}$ & $\begin{array}{l}\text { Coordinator of a } \\
\text { radio programme }\end{array}$ & $\begin{array}{l}\text { Family-oriented channel; } \\
\text { study-oriented channel }\end{array}$ \\
\hline 2013 & $\sim 30$ & $M$ & Italy & Engineering & Unemployed & $\begin{array}{l}\text { Family-oriented channel; } \\
\text { study-oriented channel }\end{array}$ \\
\hline 1982 & $\sim 70$ & $\mathrm{~F}$ & $\begin{array}{l}\text { United } \\
\text { States }\end{array}$ & Philosophy & $\begin{array}{l}\text { Self-employed } \\
\text { communication } \\
\text { coach }\end{array}$ & $\begin{array}{l}\text { Family-oriented channel; } \\
\text { study-oriented channel }\end{array}$ \\
\hline 2014 & $\sim 40$ & $M$ & Eritrea & $\begin{array}{l}\text { International } \\
\text { law }\end{array}$ & $\begin{array}{l}\text { Writer and editor in } \\
\text { an NGO }\end{array}$ & $\begin{array}{l}\text { Family-oriented channel; } \\
\text { study-oriented channel; } \\
\text { protection-oriented } \\
\text { channel }\end{array}$ \\
\hline 2008 & $\sim 30$ & $\mathrm{~F}$ & Sri Lanka & $\begin{array}{l}\text { Business; } \\
\text { Marketing; } \\
\text { Tourism }\end{array}$ & Unemployed & $\begin{array}{l}\text { Family-oriented channel; } \\
\text { study-oriented channel; } \\
\text { protection-oriented } \\
\text { channel }\end{array}$ \\
\hline 2015 & $\sim 30$ & $M$ & Iran & Engineering & Ongoing study & $\begin{array}{l}\text { Protection-oriented } \\
\text { channel; study-oriented } \\
\text { channel }\end{array}$ \\
\hline
\end{tabular}




\section{Analysis}

Several researchers have used an intersectional approach to analyse skilled migrants' access to the labour market. They have focused on interrelations between gender, ethnicity, and class to understand social actors' positions in the labour market (Riaño 2011, Raghuram 2004, Riaño et al. 2015). This study builds on an approach inspired by work on intersectionality, but it focuses on different aspects: rather than looking at individual characteristics, the study addresses the role of external support structures in migrants' trajectories. This does not mean that I dismiss other factors as unimportant but rather that I have chosen to leave them aside here to address other equally relevant elements.

This article focuses on the role of migration channels, which it studies based on interviews and observations. The channels represent different forms of institutional embeddedness that are associated with different forms of migration, and they try to capture the kinds of resources and support that migrants may have access to depending on their migration situation. This does not mean that individuals are trapped in only one channel. Various examples below show that individuals often choose to move between channels to increase their resources when their situation allows it.

I first present four different channels and then illustrate how they work at the level of the individual, using a concrete example of someone who participates in multiple channels. I do not mean to suggest that these four channels are the only ones 
This is a preprint version of an article published in the Journal of Ethnic and Migration Studies:

Laure Sandoz (2018) Understanding access to the labour market through migration channels, Journal of Ethnic and Migration Studies, DOI: 10.1080/1369183X.2018.1502657

that exist. On the contrary, there are probably many more. ${ }^{2}$ But based on my empirical analysis, these channels appear to be the most relevant for illustrating my argument.

\section{a) The family-oriented channel}

The family-oriented channel applies to people who moved to Switzerland to join a partner already living in the country. From a legal point of view, these people usually go through a family-reunification process to obtain the right to stay in the country, which may or may not be granted depending on their personal characteristics and situation (Amarelle 2012). The Swiss policy for family reunification thus plays an important role in determining the possibilities and constraints faced by people moving through this channel (Riaño 2011). Regarding labour-market access, individuals who have been granted the right to stay based on family reunification are in most cases allowed to work (Amarelle 2012).

Through my interviews, however, I observed that the legal route for family reunification is not always available, or people may have other options for acquiring a right to stay in the country. They may therefore use other channels even if their main

${ }^{2}$ When first defining the 'migration channels' concept, Findlay and his co-authors distinguished between people who individually move within the labour markets of multinational companies, people who are moved by their company to carry on offshore tasks, and people who move with the help of a recruitment agency (Findlay 1990, Findlay and Garrick 1990, Findlay and Li 1998, Findlay et al. 2013). Iredale (2001) later added two more channels to this list: mobility in the context of small recruitment agencies or ethnic networks, and recruitment through other mechanisms such as the Internet. In addition, one might think of channels for self-employed migrants such as start-up founders (Sontag 2018b) or for people who move for lifestyle reasons (Camenisch and Müller 2017); however, I focused on unemployed people looking for a job so I did not encounter these situations in my data. 
This is a preprint version of an article published in the Journal of Ethnic and Migration Studies:

Laure Sandoz (2018) Understanding access to the labour market through migration channels, Journal of Ethnic and Migration Studies, DOI: 10.1080/1369183X.2018.1502657

reason for migrating is to join a partner or another family member. This may lead to the person navigating between different channels and combining the advantages and disadvantages associated with them.

In my study, I observed that different enabling and disabling elements are associated with the family-oriented channel. On the one hand, if someone has a partner already living in the country when they arrive, they may have indirect access to people with local skills who can provide them with information and support. Furthermore, a local social network may set the basis for long-term plans and motivate the migrant to acquire new skills, such as the local language.

On the other hand, the interviews revealed that partners and their social networks are not always the best-equipped people to support newcomers. An interviewee explained that a few months after her arrival from the US, her partner recommended that she register with immigration officers. This was a mistake because the interviewee did not have any legal right to stay in the country, and she was told to leave when she contacted the authorities. Until that moment, neither she nor her partner had fully considered the constraints associated with her status as a foreigner. She eventually regularised her situation by registering at a Swiss university, which enabled her to obtain a student permit, and then later by marrying her partner.

From an institutional point of view, I observe that the external support available to reunified family members is often limited. For instance, an interviewee in charge of a newly started municipal project that aims to support highly educated foreigners in their job searches explained:

We have noticed that there is no support or little support for people who are highly qualified but who are not associated with social services or insured by the unemployment fund [. . . there is actually hardly anything for these people when 
This is a preprint version of an article published in the Journal of Ethnic and Migration Studies:

Laure Sandoz (2018) Understanding access to the labour market through migration channels, Journal of Ethnic and Migration Studies, DOI: 10.1080/1369183X.2018.1502657

they cannot get into an occupational field that corresponds to their qualifications because [. . . ] all the programs are always somehow linked to being registered as unemployed or receiving support from social services.

My data show that people who migrate to Switzerland through the familyoriented channel are first and foremost embedded into networks of relationships connected to their and their partner's personal situation. The state may take over certain responsibilities only in exceptional cases when a situation is perceived as problematic. In other cases, the migrant and the partner need to rely on their own resources, which vary from one person to another. This lack of institutional support is partly due to the political expectation that the partner is responsible for the migrant (Riaño 2003) and to the fact that the legal status of a reunified family member depends on the legal status of the person they are reunifying with (Amarelle 2012).

The Swiss government is, however, starting to invest money in programmes targeting highly educated and unemployed reunified family members (Sandoz 2018). Current debates concerning shortages of qualified workers and the need to employ the local workforce have sparked a new interest in the issue of 'brain waste' (Berthoud 2012). These debates are reframing the unemployment situation of long-term skilled migrants as a social problem that requires state intervention. In this context, measures for facilitating the recognition of foreign diplomas and for counselling migrants have been implemented (SECO 2018). At the same time, debates arguing for more restricted migration have led in some cases to stricter admission rules (Piñeiro, Bopp, and Kreis 2009). Thus, even if personal resources play a central role in shaping opportunities and constraints associated with the family-oriented channel, the state is also present as a controlling actor that may support or hinder private initiatives. 
This is a preprint version of an article published in the Journal of Ethnic and Migration Studies:

Laure Sandoz (2018) Understanding access to the labour market through migration channels, Journal of Ethnic and Migration Studies, DOI: 10.1080/1369183X.2018.1502657

\section{b) The company-oriented channel}

The company-oriented channel applies to people who have moved to Switzerland with their partner who is employed by a company in the country. In this case, both the employee and the partner are newcomers, meaning that usually neither of them has a local network of relationships upon arrival. The person with a job, however, is immediately integrated into a professional network, and the unemployed person may indirectly benefit from it. Moreover, the fact that the partner has a job guarantees a certain degree of financial security for the unemployed partner.

Companies that employ migrants are the first important source of support in this channel (Tissot 2016, Ravasi, Salamin, and Davoine 2015). Many of them offer generous relocation services to the new employees and their family because they consider that adequate support may reduce the risk of an employee's unexpected departure (Salamin and Hanappi 2014). ${ }^{3}$

Nevertheless, not all employees can access the same advantages: while companies that largely depend on a foreign skilled workforce generally use clear guidelines to define the support that relocated employees can receive, other companies

\footnotetext{
${ }^{3}$ A survey conducted by Ravasi, Salamin, and Davoine (2015) revealed that the most common relocation services offered by multinational companies to their employees in Switzerland include reimbursements for moving costs, support for finding accommodation, support with administrative issues, tax support, funding for language courses, and insurance support (in more than $70 \%$ of all cases). Other common services include funding for language courses for the spouse, support for finding a school for the children, funding for housing costs, funding for schooling costs, and organised trips to discover Switzerland before the move (in more than $50 \%$ of all cases). Some companies even provide coaching services to help trailing spouses quickly find a job after relocation, and they sometimes hire relocation agents to introduce spouses to social circles and foster their integration.
} 
This is a preprint version of an article published in the Journal of Ethnic and Migration Studies:

Laure Sandoz (2018) Understanding access to the labour market through migration channels, Journal of Ethnic and Migration Studies, DOI: 10.1080/1369183X.2018.1502657

provide minimal support or negotiate relocation packages on a case-by-case basis.

Moreover, the support offered before the move to motivate a promising candidate to accept a new position may sometimes prove to be less generous than expected (Sandoz 2018).

The gap between promises made and services delivered, the inequalities in treatment between companies, and the general tendency among businesses to reduce the costs associated with relocation support (Cartus 2014) explain why other actors have started to develop services specifically targeting the unemployed partners of relocated employees. During my field research, I was in contact with a chamber of commerce, two cantonal departments for economic promotion, and an international network of companies and volunteers, which all offer special programmes to the partners of newly arrived employees and foster their access to jobs (e.g. welcome events, networking events, trainings and coaching sessions). Yet I observe that their reasons for supporting people who have moved through the company-oriented channel are different than for those using the family-oriented channel: both spouses are seen as contributors and the risk that they may leave is perceived as an economic loss, so their well-being is given an economic value.

In sum, in the company-oriented channel, companies that employ a large number of migrants often take over responsibilities for supporting partners through relocation packages. They also sponsor other institutions, such as migrant associations, that indirectly enhance the resources available to their employees' families. State authorities at the local level also support specific projects, but it is striking that the government departments involved in the cases I observed were primarily concerned with economic promotion rather than immigration or integration. This shows that state authorities - and 
This is a preprint version of an article published in the Journal of Ethnic and Migration Studies:

Laure Sandoz (2018) Understanding access to the labour market through migration channels, Journal of Ethnic and Migration Studies, DOI: $\underline{10.1080 / 1369183 X .2018 .1502657}$

institutions in the private sector - mainly perceive this category of migrants as valuable actors who provide economic services to the places they go to. This perception has consequences since it enables migrants in the company-oriented channel to be treated as 'clients' needing support (Wagner 1998) rather than as 'others' needing control (Fassin 2011) as happens with the other channels.

\section{c) The study-oriented channel}

The study-oriented channel applies to migrants who first studied in Switzerland and then began searching for a job in the country. It also includes people who came to Switzerland for other reasons and then became affiliated with an institute of higher education.

Affiliation with an institute of higher education includes several benefits for migrants. Legally, it may give them a right to stay in the country because it is relatively easy to obtain a study or research permit (Riaño, Lombard, and Piguet 2018). Moreover, tuition fees in Switzerland are low by international standards, and Swiss universities generally charge no international student fee. This makes the country very attractive for foreign students: in 2016, Switzerland represented the second highest share of international students among OECD countries (OECD 2016).

In addition, an academic affiliation may offer time and spaces for recently arrived people to build a social network and acquire local skills and knowledge that may be useful later when looking for a job (Sandoz 2016a). It may also provide them a Swiss diploma, which gives them an advantage in comparison to other migrants whose foreign diplomas are not recognised or valued by the Swiss labour market (Zoeteweij 2016). Finally, access to services such as language classes, career and legal counselling, and alumni networks may help a person expand their resources. 
This is a preprint version of an article published in the Journal of Ethnic and Migration Studies:

Laure Sandoz (2018) Understanding access to the labour market through migration channels, Journal of Ethnic and Migration Studies, DOI: $\underline{10.1080 / 1369183 X .2018 .1502657}$

Difficulties are nevertheless likely to arise at the end of an academic affiliation.

For a long time, non-Europeans had very limited possibilities to stay and work in Switzerland after the end of their studies. Since 2011, a new policy has allowed non-EU foreigners who graduated in Switzerland to stay for six months after the end of their studies to search for a job (Riaño, Lombard, and Piguet 2018). Recent graduates may, however, only be allowed to stay if they find a job that corresponds to their field of study and is perceived as being 'of high academic or economic interest' by the authorities (art 21.3 of the Swiss Foreign Nationals Act).

EU nationals are not subject to these strict rules, but if they remain unemployed and authorities determine that they are no longer able to support themselves financially, they are asked to leave the country. ${ }^{4}$ A delicate financial situation is thus likely to affect both EU and non-EU students and researchers.

${ }^{4}$ As stipulated in the Free Movement of Persons Agreement of June 2002 between Switzerland and the European Union (FMPA), EU/EFTA citizens can freely stay in Switzerland up to 90 days, after which they need to apply for a residence permit. If they are unemployed and do not have any other legally valid reason to stay in Switzerland (e.g., family reunion or studies), they need to prove that they have health insurance and sufficient resources to support themselves (see annex I, art. 24 FMPA). Moreover, EU/EFTA nationals can only access unemployment benefits if their last employment was in Switzerland. The definition of 'sufficient resources' varies between Swiss cantons, but it is usually around CHF 2000/month. Unemployed EU/EFTA nationals who do not fulfil these requirements can in principle stay in Switzerland without a residence permit, but they are likely to experience various limitations due to the fact that they cannot officially register as residents. For 
This is a preprint version of an article published in the Journal of Ethnic and Migration Studies:

Laure Sandoz (2018) Understanding access to the labour market through migration channels, Journal of Ethnic and Migration Studies, DOI: $\underline{10.1080 / 1369183 X .2018 .1502657}$

The end of an academic affiliation can therefore place migrants in a precarious position. My interviews show that the administrative procedure for acquiring a work permit represents an obstacle for non-EU nationals in particular because either the employer is unwilling to engage in the procedure or the canton refuses the permit. A Brazilian engineer who had just graduated from a Swiss polytechnic school explained that he was offered a job in his field of studies, but the company withdrew the offer when they realised that the employer would have to apply for a work permit. In another instance, a local radio station offered a job to a Brazilian woman who had just finished her Master's in Communication, but the canton refused to grant her work authorisation.

People who have migrated using the study-oriented channel thus occupy an ambiguous position. On the one hand, foreign students are considered important to the 'scientific, technical and economic development' (CIP 2009) of Switzerland. On the other hand, a fear of the abuse of the system is very present in policy discourse (Riaño, Lombard, and Piguet 2018). There is an institutional tension between the measures that seek to enhance higher education and the measures that seek to control residence permits. This tension may lead to serious disappointment when people who were treated equally with other students realise at the end of their academic affiliation that there are barriers preventing them from accessing similar opportunities as their colleagues.

instance, they may have trouble renting or buying housing and they may receive regular letters from the municipality asking them to leave. 
This is a preprint version of an article published in the Journal of Ethnic and Migration Studies:

Laure Sandoz (2018) Understanding access to the labour market through migration channels, Journal of Ethnic and Migration Studies, DOI: 10.1080/1369183X.2018.1502657

\section{d) The protection-oriented channel}

The protection-oriented channel applies to people who have fled their country of origin and sought protection from the Swiss state. International and national laws are very important in this channel. The Geneva Convention of 1951 defines states' obligations towards refugees, the Dublin regulation determines the responsibility of affiliated member-states to examine asylum seekers' applications, and a specific policy regulates the asylum procedure in Switzerland. Therefore, people who seek protection in Switzerland are under the state's direct responsibility (Uebersax 2015). While the general tendency over the past decades has been towards an extension of rights regarding migrants using the other channels, the fight against abuses of the system has become a central objective with regard to asylum applications, and this has justified numerous revisions of the law since the 1980s (Frei et al. 2014).

Several disadvantages are associated with the protection-oriented channel. First, individuals in search of protection usually have, like many other migrants, limited locally valued skills and experience when they arrive in Switzerland. This situation, combined with the fact that the asylum procedure involves many rules that one needs to understand quickly upon arrival, contributes to making migrants highly dependent on the support that they may receive from NGOs and state institutions (UNHCR 2014).

The opportunities for working during the asylum procedure are limited.

Currently, people who have not yet been recognised as refugees need authorisation from a canton in order to accept a job, and people with a Swiss passport or valid authorisation to stay in Switzerland take precedence over them for any given job. Numerous studies have shown that these elements, combined with the fact that employers are unwilling to 
This is a preprint version of an article published in the Journal of Ethnic and Migration Studies:

Laure Sandoz (2018) Understanding access to the labour market through migration channels, Journal of Ethnic and Migration Studies, DOI: 10.1080/1369183X.2018.1502657

hire someone who could be forced to leave the country at any time, make it very difficult to find jobs (Lindenmeyer et al. 2008, Spadarotto et al. 2014, UNHCR 2014). These administrative constraints constitute, however, only one aspect of the obstacles that people in need of protection are likely to face after their arrival. Potential health problems and trauma may physically and cognitively affect their ability to adapt to new contexts (UNHCR 2014). Moreover, people fleeing their country are sometimes not able to take with them official documents attesting to their qualifications (Sontag 2018a); and even when they have these documents, the actors involved in assessing qualifications tend to attribute a lower value to qualifications originating from refugeeproducing countries (Sommer 2016). The delicate financial situation of refugees also makes it particularly difficult for them to validate their already acquired skills through additional training (Berthoud 2012), and the support structures available to them are rarely appropriate for highly educated people (Sontag 2018a, UNHCR 2014). Finally, people who have sought asylum in Switzerland are linked to a specific canton and are in principle not allowed to live elsewhere in the country or move abroad (Sontag 2018a). This means that, in contrast to other migrants, they cannot go elsewhere if they do not find opportunities suited to their situation where they live.

All these constraints limit the possibilities that people have to make decisions about their lives. Without a job, they are dependent on social welfare. They may have to live in a centre for asylum seekers. They may not know when their next interview will be or whether they have a chance of being recognised as a refugee at all. These constraints contribute to keeping them in a situation of scarcity and precariousness in which their skills become unimportant and disregarded. Interactions between institutional practices and regulations thus directly affect their lives by categorising 
This is a preprint version of an article published in the Journal of Ethnic and Migration Studies:

Laure Sandoz (2018) Understanding access to the labour market through migration channels, Journal of Ethnic and Migration Studies, DOI: 10.1080/1369183X.2018.1502657

them as 'asylum seekers' or 'refugees', when under different conditions they could have

been seen as 'highly skilled professionals'.

Table 2. Summary of the main characteristics of each channel

\begin{tabular}{|c|c|c|}
\hline Channels & Enabling factors & Disabling factors \\
\hline Family-oriented & $\begin{array}{l}\text { - Indirect access to a local social network } \\
\text { - Indirect access to locally valued skills } \\
\text { and experience } \\
\text { - If recognised as a reunified family- } \\
\text { member: same permit as the partner } \\
\text { and the possibility to work (applicable } \\
\text { to third-country nationals) }\end{array}$ & $\begin{array}{l}\text { - Residence status dependent on partner } \\
\text { (applicable to third-country nationals) } \\
\text { - Limited access to support institutions } \\
\text { - Foreign diploma } \\
\text { - Limited locally valued skills and experience }\end{array}$ \\
\hline $\begin{array}{l}\text { Company- } \\
\text { oriented }\end{array}$ & $\begin{array}{l}\text { - Indirect access to a local professional } \\
\text { network } \\
\text { - Financial security } \\
\text { - Access to support from institutions } \\
\text { targeting trailing spouses } \\
\text { - Potential support from the employer } \\
\text { - If recognised as a reunified family- } \\
\text { member: same permit as the partner } \\
\text { and the possibility to work (applicable } \\
\text { to third-country nationals) }\end{array}$ & $\begin{array}{l}\text { - Residence status dependent on partner } \\
\text { (applicable to third-country nationals) } \\
\text { - Limited local social network } \\
\text { - Foreign diploma } \\
\text { - Limited locally valued skills and experience }\end{array}$ \\
\hline Study-oriented & $\begin{array}{l}\text { - Possibility to build a network during an } \\
\text { academic affiliation } \\
\text { - Possibility to acquire locally valued skills } \\
\text { and experience during an academic } \\
\text { affiliation } \\
\text { - Local diploma } \\
\text { - Facilitated access to a residence permit } \\
\text { during an academic affiliation } \\
\text { - Access to support associated with } \\
\text { institutions of higher education }\end{array}$ & $\begin{array}{l}\text { - Precarious residence status at the end of an } \\
\text { academic affiliation (applicable to third- } \\
\text { country nationals) } \\
\text { - Delicate financial situation } \\
\text { - Limited possibility to work }\end{array}$ \\
\hline $\begin{array}{l}\text { Protection- } \\
\text { oriented }\end{array}$ & $\begin{array}{l}\text { - Legal protection framework defining } \\
\text { state responsibilities } \\
\text { - Access to support from institutions } \\
\text { targeting refugees } \\
\text { - If recognised as refugee: stable } \\
\text { residence status }\end{array}$ & $\begin{array}{l}\text { - Limited local social network } \\
\text { - Limited locally valued skills and experience } \\
\text { - Foreign diploma } \\
\text { - Delicate financial situation } \\
\text { - Limited mobility } \\
\text { - Rupture with origin country } \\
\text { - Limited possibility to work while applying for } \\
\text { refugee status } \\
\text { - Institutional support not targeted at highly- } \\
\text { educated individuals } \\
\text { - Risk of trauma and health problems }\end{array}$ \\
\hline
\end{tabular}


This overview has shown how different migration channels structure different opportunities and obstacles for migrants. The fact that these channels reflect, to a certain extent, legal ways of entering Switzerland highlights the important role of state policies in people's lives. Moreover, the analysis has shown that other actors influence support structures. These various forms of support influence the opportunities that different categories of 'highly skilled migrants' have to use their skills, depending on the resources available to them and on the perceptions that people have of them.

Nevertheless, individuals also possess the ability to manipulate these structures. In the next chapter, I introduce a case-study to illuminate the role of agency in this model. The case is illustrative in the sense that it shows how a person in a particularly delicate situation was able to mobilise resources to expand his options.

\section{Case-study}

Joseph grew up in Eritrea with his maternal grandmother, an elementary school teacher. When he was a young adult, he left his country of origin for the first time to study in South Africa. There he became politically active in a movement advocating for democratic reforms in Eritrea. Consequently, he was declared an enemy of the state and could not renew his passport. He thus became stateless.

Joseph was also finishing his $\mathrm{PhD}$ at the time. He was offered a postdoctoral fellowship at a European university and managed to obtain a passport from another 
African state. This enabled him to travel, but, as he realised later, it deprived him of the right to seek asylum in Europe.

After his first position, Joseph was employed as a postdoctoral researcher in several EU countries. He was also offered a position as an assistant professor in Canada but could not take the job because the embassy refused his visa application.

He met his partner while he was traveling for a conference. She also came from Eritrea and had been recognised as a refugee in Switzerland. After being in a longdistance relationship for a while, they decided to live together. At the time, Joseph was happy with his job and would have liked her to move to him, but because of her recently acquired refugee status, she was not able to live outside of Switzerland.

This situation convinced Joseph to move to Switzerland. His employer allowed him to keep his job and work remotely for six months, which provided him with financial security during his first half a year in Switzerland. Joseph also contacted the Swiss embassy, and they reassured him that obtaining a residence permit would not be difficult in his situation.

This prediction was, however, overly optimistic. He encountered his first obstacle when trying to get legally married so that he could apply for family reunification. This was problematic because he did not have a valid birth certificate and could not apply for a new one in his origin country given his political status. He then tried to find another solution in order to live with his partner.

Joseph started to look for ways to stay in Switzerland as a worker. He contacted several institutes of higher education but had a difficult time finding one that would support him through the administratively cumbersome admission procedure for thirdcountry workers. He was finally offered an unpaid position as a visiting researcher at a 
Swiss university, which enabled him to obtain a permit and to connect with the local academic community. This solution was only temporary, however, since he was not earning any money and his permit did not authorise him to work outside of the university.

Joseph also continued to be engaged as a political activist. He connected with new networks in Switzerland and was invited to participate in different projects as an expert. Through his partner, he also received advice about his legal situation from an organisation supporting refugees.

One year after his arrival, he was offered a fellowship by a non-governmental organisation supporting his cause. Even though this eased his difficult financial situation, it did not solve his permit problem because he could not obtain authorisation to stay in Switzerland based on the fellowship.

In the meantime, Joseph and his partner had a baby. The birth of their child was not only a happy event, but it also solved his administrative problem: because the birth dates of both parents were registered on the child's certificate, Joseph finally obtained an official document attesting to his own birth. Yet his troubles were not over. After marrying his partner, he applied for family reunification but received a negative response.

At the time of my interview, Joseph and his wife were appealing the decision with the help of a lawyer who thought that the first verdict was a mistake. Joseph was very disappointed with the immigration authorities' attitude towards him. He said:

I think that if I don't get these papers, my family reunification, my best option is to immigrate to Canada or New Zealand or the United States. [...] I don't have any other option because I don't want to remain stuck here. [...] It is not going to be 
This is a preprint version of an article published in the Journal of Ethnic and Migration Studies:

Laure Sandoz (2018) Understanding access to the labour market through migration channels, Journal of Ethnic and Migration Studies, DOI: 10.1080/1369183X.2018.1502657

easy. But me staying here without papers, I become useless! With all my experience, my academic qualifications, it's a nightmare!

$* * * * *$

This example illustrates how a single individual can navigate between several of the channels I described above. This case-study is interesting because it cannot be assigned one label: Joseph oscillates between the categories of refugee (which is not legally recognised), reunified family member (which is also not recognised), and researcher (which is hindered because of his legal status). This situation gives rise to many problems, but it also enables him to access resources and develop strategies. In this sense, Joseph's choices and decisions are partly framed by the institutional context in which he is embedded, but this does not mean that he has no agency. On the contrary, Joseph is very active in developing solutions and mobilising the resources at his disposal. These resources are obviously connected to his personal characteristics and skills, but they are also associated with his migratory situation and with other people's perception of it.

Table 3 below illustrates how Joseph has been able to mobilise resources associated with his different positions: Even though he could not be admitted as a refugee, his particular situation gave him access to the counselling services of an organisation targeting refugees and to a fellowship from an organisation willing to support his political activism. He also benefited from his wife's contacts within the asylum field. Finally, his position as an academic gave him access to new networks and provided him with a period of respite during which he could stay in Switzerland and investigate new options. 
This is a preprint version of an article published in the Journal of Ethnic and Migration Studies:

Laure Sandoz (2018) Understanding access to the labour market through migration channels, Journal of Ethnic and Migration Studies, DOI: 10.1080/1369183X.2018.1502657

Yet, Joseph was also affected by many of the disabling factors associated with the channels in which he was embedded. Even though he was unable to apply for asylum, Joseph's case involves some of the features associated with the protectionoriented channel. In particular, the brutal rupture with his origin country due to his political activism meant that he could not seek support from his government even for small matters such as a birth certificate. In addition, the fact that his wife was embedded in the protection-oriented channel indirectly affected him: her limited mobility forced him to quit a job in another country and come to Switzerland, although his legal status and lack of connections in this country affected his employment chances.

In this sense, Joseph's situation in Switzerland is closely connected to that of his wife. Even so, the Swiss state refused to recognise this connection by denying their applications for family reunification. To overcome this obstacle, Joseph was able to turn to the study-oriented channel thanks to his personal background as an academic.

Although this affiliation enabled him to meet new people and to become recognised as a scholar in Switzerland, it did not significantly ease his access to the labour market due to the university's lack of funding and the rigid admission system that prevented him from working.

I could continue this analysis by discussing further the role of other aspects. For instance, political issues associated with Joseph's nationality certainly played a role in this story. Stereotypes and discrimination associated with his racial features could also explain some of his difficulties. This would, however, go beyond the scope of this paper. My purpose was to show how different migration channels are connected with specific enabling and disabling factors, although it is obvious that these factors intersect with other categories of difference such as gender, nationality, ethnicity, race, and class. 
This is a preprint version of an article published in the Journal of Ethnic and Migration Studies:

Laure Sandoz (2018) Understanding access to the labour market through migration channels, Journal of Ethnic and Migration Studies, DOI: 10.1080/1369183X.2018.1502657

Table 3. Summary of the main characteristics for each channel, applied to Joseph's case

\begin{tabular}{|c|c|c|}
\hline Channels & Enabling factors & Disabling factors \\
\hline Family-oriented & $\begin{array}{l}\text { - Indirect access to a local social } \\
\text { network } \\
\text { - Indirect access to locally valued skills } \\
\text { and experience } \\
\text { - If recognised as a reunified family- } \\
\text { member: same permit as the partner } \\
\text { and the possibility to work (applicable } \\
\text { to third-country nationals) }\end{array}$ & $\begin{array}{l}\text { - Residence status dependent on partner } \\
\text { (applicable to third-country nationals) } \\
\text { - Limited access to support institutions } \\
\text { - Foreign diploma } \\
\text { - Limited locally valued skills and experience }\end{array}$ \\
\hline $\begin{array}{l}\text { Company- } \\
\text { oriented }\end{array}$ & $\begin{array}{l}\text { - Indirect access to a local professional } \\
\text { network } \\
\text { - Financial security } \\
\text { - Access to support from institutions } \\
\text { targeting trailing spouses } \\
\text { - Potential support from the employer } \\
\text { - If recognised as reunified a family- } \\
\text { member: same permit as the partner } \\
\text { and the possibility to work (applicable } \\
\text { to third-country nationals) }\end{array}$ & $\begin{array}{l}\text { - Residence status dependent on partner } \\
\text { (applicable to third-country nationals) } \\
\text { - Limited local social network } \\
\text { - Foreign diploma } \\
\text { - Limited locally valued skills and experience }\end{array}$ \\
\hline Study-oriented & $\begin{array}{l}\text { - Possibility to build a network during } \\
\text { academic affiliation } \\
\text { - Possibility to acquire locally valued } \\
\text { skills and experience during an } \\
\text { academic affiliation } \\
\text { - Local diploma } \\
\text { - Facilitated access to a residence permit } \\
\text { during an academic affiliation } \\
\text { - Access to support associated with } \\
\text { institutions of higher education }\end{array}$ & $\begin{array}{l}\text { - Precarious residence status at the end of an } \\
\text { academic affiliation (applicable to third- } \\
\text { country nationals) } \\
\text { - Delicate financial situation } \\
\text { - Limited possibility to work }\end{array}$ \\
\hline $\begin{array}{l}\text { Protection- } \\
\text { oriented }\end{array}$ & $\begin{array}{l}\text { - Legal protection framework defining } \\
\text { state responsibilities } \\
\text { - Access to support from institutions } \\
\text { targeting refugees } \\
\text { - If recognised as refugee: stable } \\
\text { residence status }\end{array}$ & $\begin{array}{l}\text { - Limited local social network } \\
\text { - Limited locally valued skills and experience } \\
\text { - Foreign diploma } \\
\text { - Delicate financial situation } \\
\text { - Limited mobility } \\
\text { - Rupture with origin country } \\
\text { - Limited possibility to work while applying for } \\
\text { refugee status } \\
\text { - Institutional support not targeted at highly- } \\
\text { educated individuals } \\
\text { - Risk of trauma and health problems } \\
\text { - If not recognised as refugee: precarious } \\
\text { residence status }\end{array}$ \\
\hline
\end{tabular}


This is a preprint version of an article published in the Journal of Ethnic and Migration Studies:

Laure Sandoz (2018) Understanding access to the labour market through migration channels, Journal of Ethnic and Migration Studies, DOI: $\underline{10.1080 / 1369183 X .2018 .1502657}$

\section{Conclusion}

In this article, I analysed several migration channels used by highly educated people who migrated to Switzerland without having previously found a job in the country. I discussed the enabling and disabling factors associated with these channels as well as the distribution of responsibilities between institutional actors for supporting migrants using each channel.

I proposed distinguishing between four channels. In the family-oriented channel, migrants are primarily embedded in networks of private relations with little involvement by the state or other actors, while in the company-oriented channel, companies play a central role in structuring the opportunities offered to migrants. In the study-oriented channel, migrants are first associated with an institute of higher education, with little intervention by the state, but constraints related to state control become more stringent after the end of the academic affiliation. Finally, in the protection-oriented channel, migrants are under the direct responsibility of the state, which grants protection on the one hand but also defines numerous obligations and constraints to discourage abusive behaviours on the other. These different configurations of responsibilities and power entail different perceptions of migrants: while some tend to be defined by their economic potential, others are more likely to be suspected of abuse. Such representations impact the forms of control and support present in each channel, thus affecting the opportunities offered to migrants and their status as 'highly skilled'.

This article contributes to existing theories on highly skilled migration in three main ways. First, the concept of migration channels enables us to question the artificial nature of migrant categories. Although the migration of the 'highly skilled' is usually viewed as higher-end, more sought-after, and freer of constraints than other forms of 
This is a preprint version of an article published in the Journal of Ethnic and Migration Studies:

Laure Sandoz (2018) Understanding access to the labour market through migration channels, Journal of Ethnic and Migration Studies, DOI: 10.1080/1369183X.2018.1502657

migration (Favell, Feldblum, and Smith 2006, Scott 2006), an approach that takes into account the specific opportunities and obstacles associated with different channels shows that skills are not all that matters. Beyond individual characteristics, the way people are embedded in supportive or constraining environments that do or do not enable them to build upon their already existing resources is central to shaping their social status and life options.

Second, a migration channel approach highlights the complex interplay between structures and agency (Goss and Lindquist 1995, Findlay and Li 1998). Migrants are not passive agents. They actively develop strategies to adapt to the constraints imposed on them and to fulfil their personal aspirations. Nevertheless, they also depend on the range of opportunities available in their immediate environment, and the possibility to navigate between channels relies on their ability to mobilise these options effectively. A comprehensive analysis of migration situations needs to account for the power of categories on people's lives as well as for the individuals' ability to navigate these categories.

Finally, a migration channel approach highlights the role of both state and nonstate actors in defining and selecting 'wanted' or 'good' migrants (Van Riemsdijk, Basford, and Burnham 2015, Findlay et al. 2013, Hercog and Sandoz 2018a). Migration is never solely an individual project: it is also a business in which various actors have stakes (Groutsis, Van den Broek, and Harvey 2015, Cranston, Schapendonk, and Spaan 2017), and it involves major political issues concerning who should be allowed to live and participate in a given society (Favell 2008). Understanding how different actors shape opportunities and constraints for different groups of migrants is crucial if we want research to remain an independent field of knowledge-production that provides 
This is a preprint version of an article published in the Journal of Ethnic and Migration Studies:

Laure Sandoz (2018) Understanding access to the labour market through migration channels, Journal of Ethnic and Migration Studies, DOI: 10.1080/1369183X.2018.1502657

alternative perspectives on societal processes. The concept of 'migration channel'

contributes to this endeavour by enabling a critical yet empathic analysis of migration situations.

\section{Acknowledgement}

This research was supported by the National Centre of Competence in Research nccr - on the move, funded by the Swiss National Science Foundation. I wish to thank my colleagues Metka Hercog and Katrin Sontag who contributed to the field research by conducting some of the interviews and who offered valuable ideas and feedback throughout the research process. I also would like to thank the two anonymous reviewers and the editors of this journal for their helpful comments on earlier drafts. 
This is a preprint version of an article published in the Journal of Ethnic and Migration Studies:

Laure Sandoz (2018) Understanding access to the labour market through migration channels, Journal of Ethnic and Migration Studies, DOI: 10.1080/1369183X.2018.1502657

\section{References}

Amarelle, Cesla. 2012. "Aspects normatifs généraux et enjeux en matière de regroupement familial." In Migrations et regroupement familial, edited by Cesla Amarelle, Nathalie Christen and Minh Son Nguyen, 11-70. Bern: Stämpfli.

Atkinson, Rowland, and John Flint. 2004. "Snowball Sampling." In The SAGE Encyclopedia of Social Science Research Methods, edited by Michael S. LewisBeck, Alan Bryman and Tim Futing Liao. Sage.

Berthoud, Carole. 2012. Dequalifiziert! Das ungenutze Wissen von Migrantinnen und Migranten in der Schweiz: Mit Porträts von Betroffenen und Handlungsempfehlungen. In Im Fokus: Gesundheit, Migration. Bern: Schweizerisches Rotes Kreuz.

Boswell, Christina, Silvia Stiller, and Thomas Straubhaar. 2004. Forecasting Labour and Skills Shortages: How Can Projections Better Inform Labour Migration Policies? . Hambourg: Paper prepared for the European Commission, DG Employment and Social Affairs.

Boucher, Anna, and Lucie Cerna. 2014. "Current Policy Trends in Skilled Immigration Policy." International Migration 52 (3):21-25.

Bruland, Silja K., and Grete Rusten. 2011. "Sourcing strategies, channels and geographies in the international recruitment of highly skilled work-force: A case study of companies in the petroleum and maritime sectors in a non-urban location in Norway." Erdkunde 66 (1):1-11.

Camenisch, Aldina, and Seraina Müller. 2017. "From (E)Migration to Mobile Lifestyles: Ethnographic and Conceptual Reflections about Mobilities and Migration." New Diversities 19 (3):43-57.

Cartus. 2014. Talent Management and the Changing Assignee Profile. 2013 Survey Report. Cartus. Trends in Global Relocation.

Cerna, Lucie. 2013. "The EU Blue Card: Preferences, Policies, and Negotiations between Member States." Migration Studies 2 (1):73-96.

CIP. 2009. Initiative parlementaire: Faciliter l'admission et l'intégration des étrangers diplômés d'une haute école suisse. Avant-projet et rapport explicatif de la Commission des institutions politiques du Conseil national.

Collett, Elizabeth, Paul Clewett, and Susan Fratzke. 2016. No Way Out? Making Additional Migration Channels Work for Refugees. Washington DC: Migration Policy Institute.

Cranston, Sophie, Joris Schapendonk, and Ernst Spaan. 2017. "New Directions in Exploring the Migration Industries: Introduction to Special Issue." Journal of Ethnic and Migration Studies 44 (4):543-557.

Docquier, Frédéric, Olivier Lohest, and Abdeslam Marfouk. 2005. "Union européenne et migrations internationales : L'UE15 contribue-t-elle à l'exode des travailleurs qualifiés ?" Revue Économique 56 (6):1301-1330.

European Commission. 2016. Verbesserung der legalen Migrationskanäle: Kommission schlägt EU-Neuansiedlungsrahmen vor. Brussels.

Fassin, Didier. 2011. "Policing Borders, Producing Boundaries. The Governmentality of Immigration in Dark Times." Annual Review of Anthropology 40 (1):213-226. 
Favell, Adrian. 2008. "Rebooting Migration Theory. Interdisciplinarity, Globality, and Postdisciplinarity in Migration Studies." In Migration Theory. Talking across Disciplines, edited by Caroline B. Brettell and James F. Hollifield, 259-278. New York: Routledge.

Favell, Adrian, Miriam Feldblum, and Michael Peter Smith. 2006. "The Human Face of Global Mobility. A Research Agenda." In The Human Face of Global Mobility: International Highly Skilled Migration in Europe, North America and the AsiaPacific, edited by Michael Peter Smith and Adrian Favell, 1-25. New Brunswick, NJ: Transaction Publishers.

Findlay, Allan. 1990. "A migration channels approach to the study of high level manpower movements: a theoretical perspective." International Migration 28 (1):15-23.

Findlay, Allan, and Lesley Garrick. 1990. "Scottish Emigration in the 1990s: A Migration Channels Approach to the Study of Skilled International Migration." The Royal Geographical Society 15 (2):177-192.

Findlay, Allan, and F. L. N. Li. 1998. "A Migration Channels Approach to the Study of Professionals Moving to and from Hong Kong." International Migration Review 32 (3):682-703.

Findlay, Allan M., David McCollum, Sergei Shubin, Elina Apsite, and Zaiga Krisjane. 2013. "The role of recruitment agencies in imagining and producing the 'good' migrant." Social \& Cultural Geography 14 (2):145-167.

Frei, Nula, Teresia Gordzielik, Clément de Senarclens, Anne-Cécile Leyvraz, and Robin Stünzi. 2014. "La lutte contre les abus dans le domaine de l'asile : Emergence et développement d'un discours structurant le droit d'asile suisse." Jusletter March 17.

Glaser, Barney G., and Anselm L. Strauss. 1967. The Discovery of Grounded Theory: Strategies for Qualitative Research. New Brunswick: Aldine Transaction.

Goss, Jon, and Johan Lindquist. 1995. "Conceptualizing International Labor Migration: A Structuration Perspective." International Migration Review 29 (2):317-351.

Groutsis, Dimitria, Diane Van den Broek, and William Harvey. 2015. "Transformations in Network Governance: The Case of Migration Intermediaries." Journal of Ethnic and Migration Studies 41 (10):1558-1576.

Hercog, Metka, and Laure Sandoz. 2018a. "Highly Skilled or Highly Wanted Migrants? Conceptualizations, Policy Designs and Implementations of High-skilled Migration Policies." Migration Letters 15 (4).

Hercog, Metka, and Laure Sandoz. 2018b. "Selecting the Highly Skilled: Norms and practices in the Swiss admission regime for non-EU immigrants." Migration Letters 15 (4).

Iredale, Robyn. 2001. "The Migration of Professionals: Theories and Typologies." International Migration 39 (5):7-24.

Kaufmann, Vincent, Manfred Bergman, M., and Dominique Joye. 2004. "Motility. Mobility as Capital." International Journal of Urban and Regional Research 28 (4):745-756.

Kofman, Eleonore. 2014. "Towards a Gendered Evaluation of (Highly) Skilled Immigration Policies in Europe." International Migration 52 (3):116-128. 
Lindenmeyer, Hannes, Barbara Von Glutz, Fiona Häusler, and Franz Kehl. 2008. Arbeitsmarktintegration von Flüchtlingen und Vorläufig Aufgenommenen. Studie über erfolgversprechende Faktoren. Bern: KEK-CDC Consultants on behalf of the Bundesamt für Migration.

Lowell, Lindsay B., and Johanna Avato. 2014. "The Wages of Skilled Temporary Migrants: Effects of Visa Pathways and Job Portability." International Migration $52(3): 85-98$.

Mau, Steffen, Heike Brabandt, Lena Laube, and Christof Roos. 2012. Liberal States and the Freedom of Movement: Selective Borders, Unequal Mobility. London: Palgrave Macmillan.

Mau, Steffen, Fabian Gülzau, Lena Laube, and Natascha Zaun. 2015. "The Global Mobility Divide: How Visa Policies Have Evolved over Time." Journal of Ethnic and Migration Studies 41 (8):1192-1213.

Mozetic, Katarina. 2018. "Being Highly Skilled and a Refugee: Self-Perceptions of NonEuropean Physicians in Sweden." Refugee Survey Quarterly 0:1-21.

Müller-Jentsch, Daniel. 2008. "Humankapital als mobile Ressource." In Die Neue Zuwanderung: Die Schweiz zwischen Brain-Gain und Überfremdungsangst edited by Daniel Müller-Jentsch, 285-308. Zürich: NZZ Libro.

nccr - on the move. 2017. "Migration-Mobility Indicators." accessed 10.1.2018. http://nccr-onthemove.ch/knowledge-transfer/migration-mobility-indicators/.

OECD. 2008. The Global Competition for Talent. Mobility of the Highly Skilled. Paris: OECD.

OECD. 2016. Education at a Glance 2016: OECD Indicators. Paris: OECD.

OECD/EU. 2015. Les indicateurs de l'intégration des immigrés 2015: Trouver ses marques. Paris: OECD.

OHCHR. 2016. "Migration control is not only about keeping people out - UN experts call for vision and leadership." United Nations Human Rights Office of the High Commissioner, accessed 15.12.2017. http://www.ohchr.org/EN/NewsEvents/Pages/DisplayNews.aspx?NewsID=207 44\&LangID=E.

Parsons, Christopher, Sebastien Rojon, Farhan Samanani, and Lena Wettach. 2014. "Conceptualising International High-Skilled Migration." The IMI Working Paper Series 104:1-26.

Piñeiro, Esteban, Isabelle Bopp, and Georg Kreis. 2009. Fördern und Fordern im Fokus. Leerstellen des Schweizerischen Integrationsdiskurses. Zürich: Seismo.

Raghuram, Parvati. 2004. "The Difference that Skills Make: Gender, Family Migration Strategies and Regulated Labour Markets." Journal of Ethnic and Migration Studies 30 (2):303-321.

Ravasi, Claudio, Xavier Salamin, and Eric Davoine. 2015. "Cross-cultural Adjustment of Skilled Migrants in a Multicultural and Multilingual Environment: An Explorative Study on Foreign Employees and their Spouses in the Swiss Context." The International Journal of Human Resource Management 26 (10):1335-1359.

Riaño, Yvonne. 2003. "Migration of Skilled Latin American Women to Switzerland and Their Struggle for Integration." In Emigración Latinoamericana: Comparación Interregional entre América del Norte, Europea y Japón., edited by Mutsuo 
Yamada, 1-32. Osaka: The Japan Centre for Area Studies, National Museum of Ethnology.

Riaño, Yvonne. 2011. "Drawing New Boundaries of Participation: Experiences and Strategies of Economic Citizenship among Skilled Migrant Women in Switzerland." Environment and Planning A 43:1530-1546.

Riaño, Yvonne, Katharina Limacher, André Aschwanden, Sophie Hirsig, and Doris Wastl-Walter. 2015. "Shaping Gender Inequalities: Critical Moments and Critical Places." Equality, Diversity and Inclusion: An International Journal 34 (2):155-167.

Riaño, Yvonne, Annique Lombard, and Etienne Piguet. 2018. "How to explain migration policy openness in times of closure? The case of international students in Switzerland." Globalisation, Societies and Education 16 (3):295-307.

Salamin, Xavier, and Doris Hanappi. 2014. "Women and international assignments." Journal of Global Mobility 2 (3):343-374.

Sandoz, Laure. 2016a. "'Si tu perds ton travail, c'est fini'." terra cognita 29 (Autumn):102-103.

Sandoz, Laure. 2016b. "The Symbolic Value of Quotas in the Swiss Immigration System." highlights, e-magazine of the nccr-on the move 1:40-45.

Sandoz, Laure. 2018. "Intermediaries, Channels and Privileges: A Journey into the Mobility of the 'Highly Skilled' towards Switzerland." Unpublished PhD thesis, Institute of Cultural Anthropology and European Ethnology, University of Basel.

Sandoz, Laure, and Fabian Santi. [forthcoming in 2018]. "Who Receives more Help? The Role of Employer Support in Migration Processes." In Changing realities of migration and mobility. The Swiss case, edited by Philippe Wanner and Ilka Steiner. Springer International Publishing.

Scott, Sam. 2006. "The Social Morphology of Skilled Migration: The Case of the British Middle Class in Paris." Journal of Ethnic and Migration Studies 32 (7):11051129.

SECO. 2018. "Initiative visant à combattre la pénurie de personnel qualifié: mieux exploiter le potentiel indigène." State Secretariat for Economic Affairs, accessed 2 May 2018. https://www.seco.admin.ch/seco/fr/home/Arbeit/Fachkraefteinitiative.html.

Sommer, Ilka. 2016. "Gleichwertigkeit prüfen? Die (Nicht-) Anerkennung ausländischer Qualifikationen und die symbolische Gewalt im transnationalen Bildungsfeld." In Symbolische Ordnung und Bildungsungleichheit in der Migrationsgesellschaft, Interkulturelle Studien, edited by Emre Arslan and Kemal Borzay, 373-388. Wiesbaden: Springer.

Sontag, Katrin. 2018a. "Highly Skilled Asylum Seekers. The Case of Refugee Students at a Swiss University." Migration Letters 15 (4).

Sontag, Katrin. 2018b. Mobile Entrepreneurs. An Ethnographic Study of the Migration of the Highly Skilled. Opladen: Budrich UniPress.

Spadarotto, Claudio, Maria Bieberschulte, Katharina Walker, Michael Morlok, and Andrea Oswald. 2014. Erwerbsbeteiligung von anerkannten Flüchtlingen und vorläufig Aufgenommenen auf dem Schweizer Arbeitsmarkt. KEK-CDC 
Consultants and B,S,S. Volkswirtschaftliche Beratung, on behalf of the Bundesamt für Migration.

Swiss Federal Council. 2002. Message concernant la loi sur les étrangers, FF 20023469. Bern: Swiss Confederation.

Tannock, Stuart. 2011. "Points of Prejudice: Education-Based Discrimination in Canada's Immigration System." Antipode 43 (4):1330-1356.

Tissot, Florian. 2016. "Highly-Skilled Labour Migration in Switzerland: Household Strategies and Professional Careers." Working Paper Series "Gender, Diversity and Migration", no. 10 Goethe University Frankfurt:1-28.

Uebersax, Peter. 2015. "Zum bundesrätlichen Vernehmlassungsentwurf zur Umsetzung von Art. 121a BV." Jusletter 16 (March):1-15.

UNHCR. 2014. Arbeitsmarktintegration. Die Sicht der Flüchtlinge und vorläufig Aufgenommenen in der Schweiz. Geneva: UNHCR.

Van den Broek, Di, Will S. Harvey, and Dimitri Groutsis. 2015. "Commercial Migration Intermediaries and the segmentation of skilled migrant employment." Work, employment \& Society 30 (3):523-534.

Van Riemsdijk, Micheline, Scott Basford, and Alana Burnham. 2015. "Socio-Cultural Incorporation of Skilled Migrants at Work: Employer and Migrant Perspectives." International Migration 54 (3):20-34.

Wagner, Anne-Catherine. 1998. Les nouvelles élites de la mondialisation: Une immigration dorée en France. Paris: Presses Universitaires de France.

Xiang, Biao. 2007. Global 'Body Shopping': An Indian Labor System in the Information Technology Industry. Princeton: Princeton University Press.

Xiang, Biao, and Johan Lindquist. 2014. "Migration Infrastructure." International Migration Review 48 (1):122-148.

Yeoh, Brenda S.A., and Shirlena Huang. 2011. "Introduction: Fluidity and Friction in Talent Migration." Journal of Ethnic and Migration Studies 37 (5):681-690.

Yuval-Davis, Nira, Georgie Wemyss, and Kathryn Cassidy. 2017. "Everyday Bordering, Belonging and the Reorientation of British Immigration Legislation." Sociology:1-17.

Zoeteweij, Margarite H. . 2016. "Die Anerkennung von Berufsqualifikationen vereinfachen." In Migrationsland Schweiz: 15 Vorschläge für die Zukunft, edited by Christine Abbt and Johan Rochel, 199-210. Baden: Hier und Jetzt.

Zschirnt, Eva, and Didier Ruedin. 2016. "Ethnic Discrimination in Hiring Decisions: A Meta-Analysis of Correspondence Tests 1990-2015." Journal of Ethnic and Migration Studies 42 (7):1115-1134. 